\title{
Selectivity of the Effects of Guanosine-5'-O-(2-thiodiphosphate) on Agonist Inhibition of the M-Current in Amphibian Sympathetic Neurons
}

\author{
Mark A. Simmons and Robert J. Mather \\ The Neuropharmacology Laboratory, Department of Pharmacology, Marshall University, Huntington, \\ West Virginia 25755-9310
}

In bullfrog sympathetic neurons, luteinizing hormone-releasing hormone, muscarine, and substance $P$ act as agonists at specific membrane receptors to decrease a potassium current, $I_{M}$. The receptors are coupled to guanine nucleotide-binding proteins (G-proteins). Whole-cell recordings of $I_{M}$ were made from isolated bullfrog sympathetic neurons to examine the effects of intracellularly applied guanosine-5'-O-(2-thiodiphosphate) (GDP $\beta S$ ) on agonist inhibition of $I_{M}$. Successive responses to a given agonist were decreased in the presence of GDP $\beta$ s. Subsequent responses to the other agonists were then measured to determine the degree of overlap of the effect of GDP $\beta S$ for the different agonists. GDP $\beta$ S selectively inhibited successive responses to one agonist such that a subsequent application of a different agonist was still effective. If GDP $\beta$ S acts at the level of the G-protein, this suggests that each receptor is coupled to a separate population of G-proteins. Alternatively, GDP $\beta$ S may act at the receptor level to block receptor coupling to $I_{M}$.

Neurotransmitters act through G-proteins to affect several distinct potassium currents in a variety of neuronal cell types (Brown, 1990). Neurons of the sympathetic ganglia of the bullfrog possess a time- and voltage-dependent potassium current termed the M-current $\left(I_{M} ;\right.$ Brown and Adams, 1980). Three different classes of neurotransmitters inhibit $I_{\mathrm{M}}$ : agonists at muscarinic cholinergic receptors, at substance $\mathrm{P}$ (SP) receptors, and at luteinizing hormone-releasing hormone (LHRH) receptors.

Normally, the M-current is observed as an outward potassium current at membrane potentials between $-30 \mathrm{mV}$ and $-60 \mathrm{mV}$. In this potential range, $I_{M}$ is the major contributor to the membranc conductance when the cell is not firing an action potential. $I_{\mathrm{M}}$ limits the ability of synaptic inputs to sum and, thereby, to provoke an action potential in the cell. When $I_{\mathrm{M}}$ is decreased, however, the likelihood that subthreshold synaptic inputs will reach the action-potential threshold is increased. Consequently, $I_{\mathrm{M}}$ is an important regulator of cellular excitability (Brown, 1988).

The precise mechanism by which the binding of an agonist to a membrane receptor results in a closure of M-channels is not known. There is evidence, however, that at least one of the

\footnotetext{
Received Nov. 9, 1990; revised Jan. 28, 1991; accepted Feb. 27, 1991.

This work was supported by NIH Grant NS-25999. We thank Drs. T. M. Egan, H. C. Hartzell, and E. C. Johnson for helpful discussions.

Correspondence should be addressed to Mark A. Simmons, Ph.D., at the above address.

Copyright (C) 1991 Society for Neuroscience $0270-6474 / 91 / 112130-05 \$ 03.00 / 0$
}

steps between the receptor and the M-channel involves a guanine nucleotide-binding protein (G-protein; Pfaffinger, 1988; Brown et al., 1989; Lopez and Adams, 1989). When compounds known to activate G-proteins, such as guanylyl-imidodiphosphate (GMP-PNP), guanosine-5' $O$-(3-thiotriphosphate) (GTP$\gamma-\mathrm{S})$, or $\mathrm{AlF}_{4}^{-}$, are applied intracellularly, the M-current decreases, even in the absence of agonist. In the presence of a nonhydrolyzable GTP analog, such as GMP-PNP or GTP- $\gamma-S$, the inhibition of $I_{\mathrm{M}}$ by $t$-LHRH, D-Ala ${ }^{6}$ LHRH, muscarine, or $\mathrm{SP}$ is not reversible or is only partially reversible. Finally, intracellular application of guanosine-5'-O-(2-thiodiphosphate) (GDP $\beta$ S) decreases the effectiveness of LHRH or muscarine to inhibit $I_{\mathrm{M}}$ (Pfaffinger, 1988; Brown et al., 1989; Lopez and Adams, 1989). It is not known whether there is any selectivity of GDP $\beta$ S toward the responses to LHRH, muscarine, and SP or whether GDP $\beta$ S affects the responses to all three agonists in the same manner.

\section{Materials and Methods}

Single cells were isolated from Rana catesbiana as described previously (Simmons et al., 1990). Whole-cell recordings were made with electrodes of $0.25-1 \mathrm{M} \Omega$ filled with $120 \mathrm{~mm} \mathrm{KCl}, 2 \mathrm{~mm} \mathrm{MgCl}, 5 \mathrm{~mm}$ EGTA, 10 mM HEPES, $1.5 \mathrm{~mm}$ ATP, and $10 \mathrm{~nm}$ leupeptin, pH 6.8 (with $\mathrm{KOH}$ ), plus various concentrations of guanine nucleotides as indicated. The extracellular solution contained $118 \mathrm{~mm} \mathrm{NaCl}, 2.4 \mathrm{~mm} \mathrm{KCl}, 1.8 \mathrm{~mm}$ $\mathrm{CaCl}_{2}, 1.8 \mathrm{mM} \mathrm{MgCl}_{2}, 5 \mathrm{~mm}$ sodium pyruvate, $5 \mathrm{~mm}$ glucose, $10 \mathrm{~mm}$ HEPES, and $300 \mathrm{~nm}$ tetrodotoxin, $\mathrm{pH} 7.4$ (with $\mathrm{NaOH}$ ).

Cells were placed in a Petri dish on the stage of an inverted microscope for whole-cell recording. The bath was constantly perfused with control extracellular solution at $8 \mathrm{ml} / \mathrm{min}$. Drugs were applied by a single-cell superfusion system similar to that used previously (Yellen, 1982; Fischmeister and Hartzell, 1986). Once a whole-cell recording was established, the electrode was moved so that the cell was positioned in front of the opening of one in a row of glass capillary tubes with $250 \mu \mathrm{m}$ i.d. Each capillary was connected by silicon elastomer tubing to a $10-\mathrm{ml}$ syringe mounted $15 \mathrm{~cm}$ above the microscope stage. Hydrostatic pressure resulted in a flow rate of approximately $10 \mu \mathrm{l} / \mathrm{min}$ from the opening. To change the superfusing solution, the row of tubes was moved horizontally so that the cell was positioned in front of the desired opening. Those tubes not in front of the cell were clamped. With this method, the extracellular solution surrounding the cell of interest can be changed within about $200 \mathrm{msec}$, drug application to one cell does not require that the entire bath be flooded with drug, and other cells in the bath are not exposed to drug.

$I_{\mathrm{M}}$ was monitored by $500-\mathrm{msec}$ pulses from a holding potential of $-30 \mathrm{mV}$ to $-50 \mathrm{mV}$ every $8 \mathrm{sec}$. Our measurement of $I_{\mathrm{M}}(-30)$ is illustrated in Figure 1. All experiments were conducted at room temperature $\left(\approx 20^{\circ} \mathrm{C}\right)$.

Most chemicals were obtained from Sipma Chemical Corporation or Fisher Scientific. Nucleotides and SP were .. 'm Boehringer-Mannheim, cII-LHRH was from Peninsula Laboratories, nd muscarine was from Research Biochemicals Inc. 


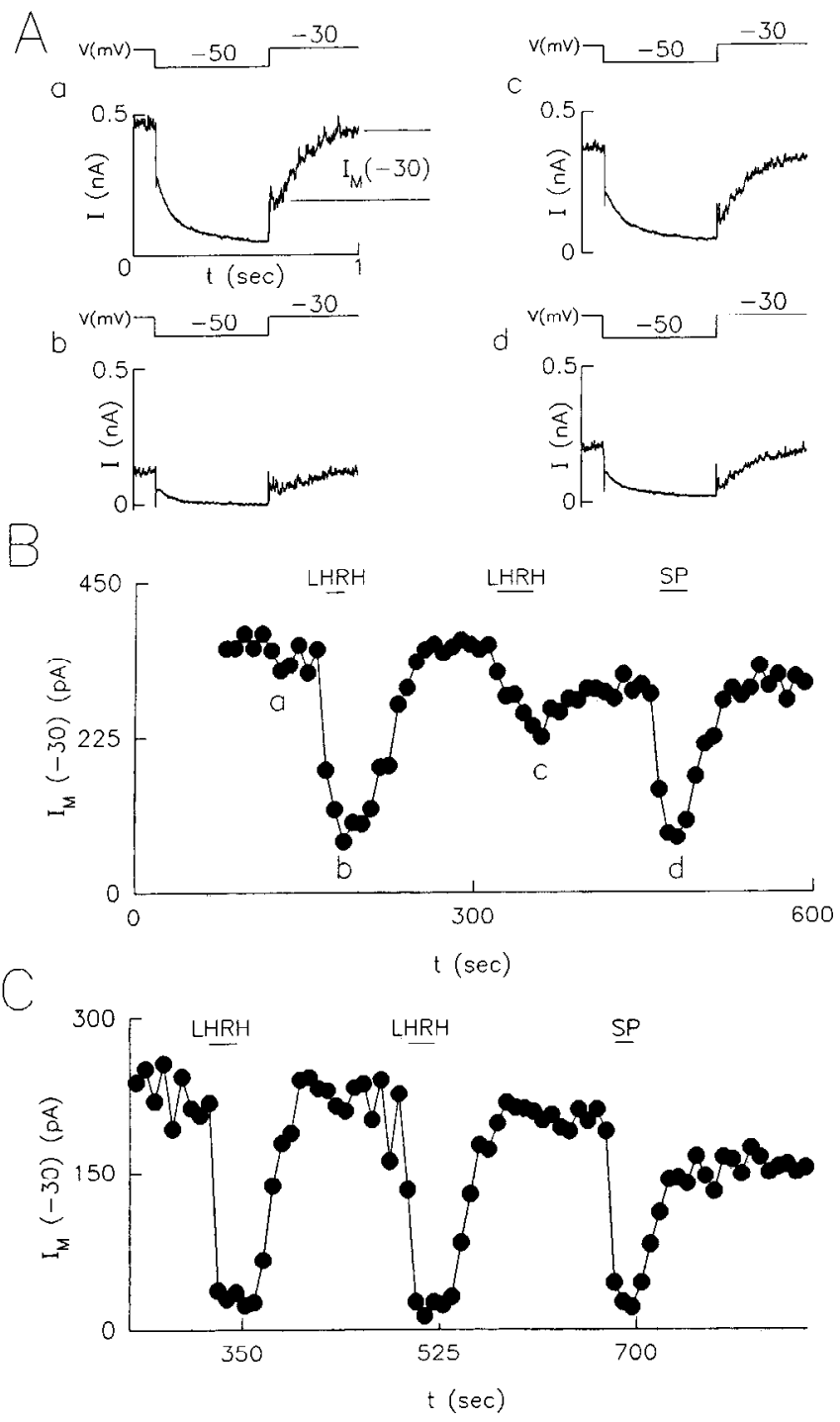

Figure 1. GDPBS inhibits the responsiveness to LHRH without affecting the response to SP. $A$, Sample tracings of cell current obtained before $(a)$ and during $(b)$ the first LHRH (100 nM) application, during the second LHRH application (c), and during the SP $(1 \mu \mathrm{M})$ application (d). As illustrated above the current tracings, the voltage was stepped from -30 to $-50 \mathrm{mV}$ for $500 \mathrm{msec}$ and then returncd to $30 \mathrm{mV}$. $I_{\mathrm{M}}(-30)$ was measured as the amplitude of the current relaxation upon returning to $-30 \mathrm{mV}$ from $-50 \mathrm{mV}$, as shown in $a$. $B, I_{\mathrm{M}}(-30)$ versus time with $750 \mu \mathrm{M}$ GDP $\beta S$ and $100 \mu \mathrm{M}$ GTP in the recording electrode. The first application of LHRH resulted in a large decrease of $I_{\mathrm{M}}(-30)$ (b). The response to the second LHRH application was much smaller (c), but SP was still able to inhibit $I_{\mathrm{M}}(d)$. C, Control cell with $400 \mu \mathrm{M}$ GTP in the recording electrode. Drug applications were applied at the same intervals as in $B$. In this case, the second response to LHRH was not decreased.

The LHRH concentration was 100 or $300 \mathrm{nM}$, the muscarine concentration was 10 or $20 \mu \mathrm{M}$, and the SP concentration was $1 \mu \mathrm{M}$. These doses are at or near maximal for inhibition of $I_{\mathrm{M}}$ and would be expected to produce the greatest degree of activation of G-proteins. The cell-tocell variability in responsiveness is minimized at these concentrations. Because not every sympathetic neuron responds to all of the agonists, the data include only those cells that displayed an inhibition of $I_{M}(-30)$ in response to the agonists under study. Agonists were applied only long enough for the change in $I_{\mathrm{M}}$ to reach a steady state.

The amount of GDP $\beta S$ is indicated as the GDP $\beta S: G T P$ ratio rather than absolute concentration (Breitwieser and Szabo, 1988). GTP concentrations varied from 40 to $100 \mu \mathrm{M}$, but in most experiments total
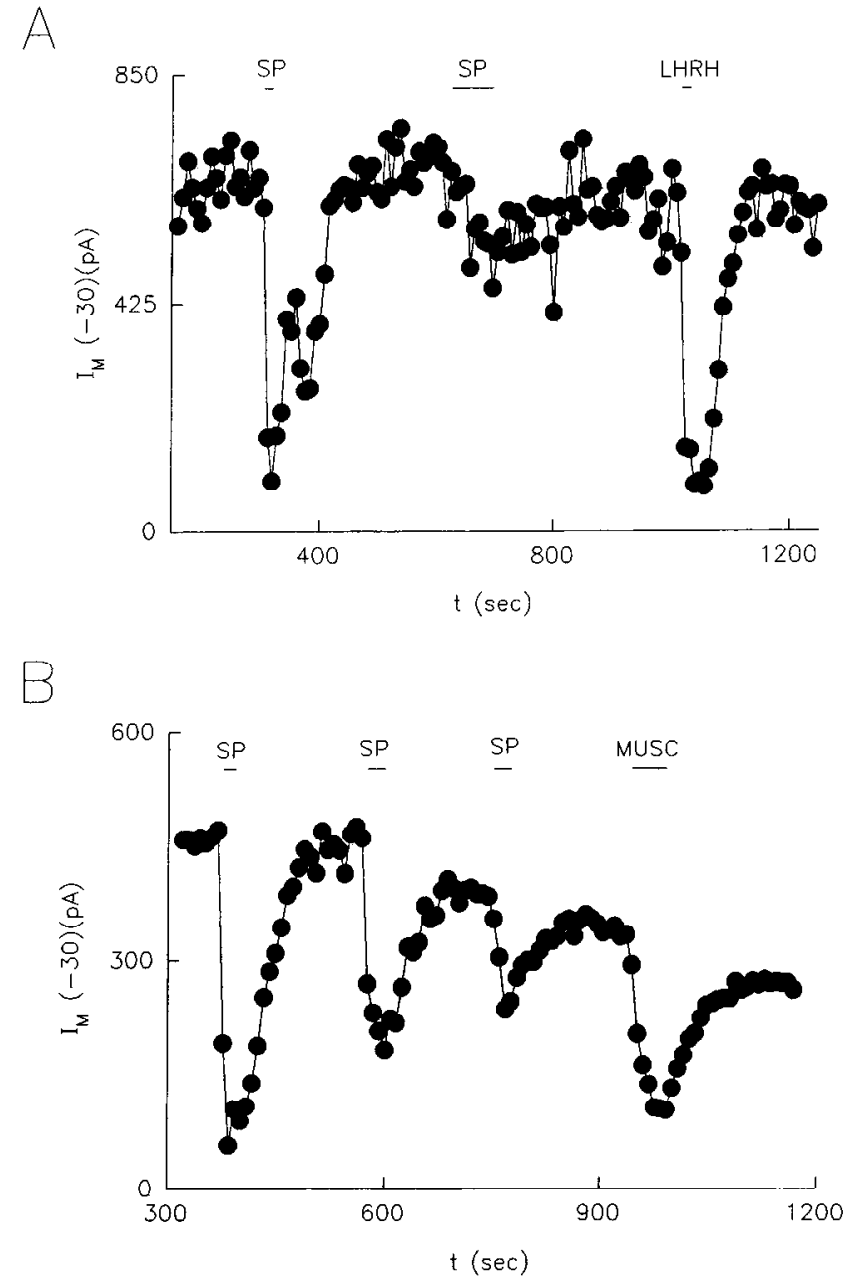

Figure 2. GDP $\beta$ S decreases successive responses to SP but not subsequent responses to LHRH or muscarine. $A$, The recording electrode contained $320 \mu \mathrm{M}$ GDP $\beta$ S and $80 \mu \mathrm{M}$ GTP. The first application of SP $(1 \mu \mathrm{M})$ decreased $I_{\mathrm{M}} 86 \%$, and the second SP application, only $21 \%$. LHRH $(100 \mathrm{nM})$ then inhibited $I_{\mathrm{M}}$ by $85 \%$. $B$, Successive responses to $\mathrm{SP}(1 \mu \mathrm{M})$ in this cell were less sensitive to the same concentrations of GDP $\beta$ S and GTP as in $A$. The responses to SP decreased from an $87 \%$ inhibition of $I_{\mathrm{M}}$ to a $43 \%$ inhibition of $I_{\mathrm{M}}$ at the third SP application. Subsequently, muscarine (MUSC; $10 \mu \mathrm{M}$ ) was able to inhibit $I_{\mathrm{M}}$ by $69 \%$.

guanine nucleotide concentration in the pipette was $400 \mu \mathrm{M}$. For control cells, the [GTP] was 40 or $400 \mu \mathrm{M}$, as indicated in the figure captions.

Values are expressed as mean \pm standard deviation and were compared statistically by $t$ tests. Time is expressed as the time from the start of the experiment, which was 30-60 sec after breaking the patch.

\section{Results}

In bullfrog sympathetic neurons perfused with an intracellular solution containing GTP, consecutive agonist applications resulted in reproducible decreases in $I_{\mathrm{M}}$; however, when GDP $\beta S$ was added to the intracellular solution, the degree of inhibition of $I_{\mathrm{M}}$ decreased with successive agonist applications. In the cell of Figure 1, $A$ and $B$, the intracellular solution contained GDP $\beta$ S: GTP $=7.5: 1$. The first application of LHRH resulted in a $79 \%$ inhibition of $I_{\mathrm{M}}$ (Fig. $1 A b, B b$ ), but the second application of LHRH only decreased $I_{\mathrm{M}}$ by $36 \%$ (Fig. $1 A c, B c$ ). Although the LHRH responses were now decreased, the responsiveness to SP appeared normal (Fig. 1 $A d, B d$ ). To ensure that the decreased responsiveness was due to GDP $\beta$ S and not simply the result of 


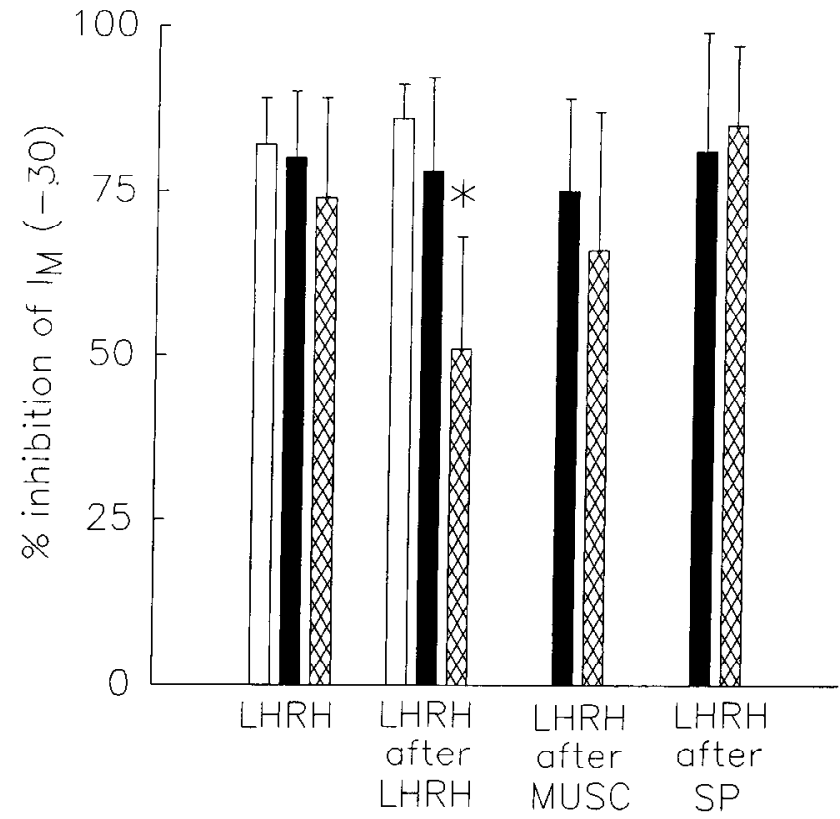

Figure 3. Inhibition of $I_{\mathrm{M}}$ by LHRH. The set of bars labeled $L H R H$ shows the response to the first LHRH application with $40 \mu \mathrm{M}$ GTP ( $n$ $=5$; open bar $), 400 \mu \mathrm{M}$ GIP $(n=15$; solid bar $)$, or GDP $\beta$ S:GTP $(n=$ 1 at 5.75:1, 6 at 7.5:1, and 8 at 9:1; crosshatched bar). The set of bars labeled $L H R H$ after $L H R H$ shows the response to LHRH after an average of two (range, 1-3) previous LHRH applications with $40 \mu \mathrm{M}$ GTP ( $n=5$; open bar $), 400 \mu \mathrm{M}$ GTP $(n=15$; solid bar $)$, or GDP $\beta$ : GTP $(n=1$ at $5.75: 1,6$ at $7.5: 1$, and 8 at $9: 1$; crosshatched bar). The set of bars labeled LHRH after MUSC shows the response to LHRH after an average of three (range, 2-4) previous muscarine applications with $400 \mu \mathrm{M}$ GTP $(n=10$; solid bar) or GDP $\beta$ S:GTP $(n=5$ at $7.5: 1$ and 5 at 9:1; crosshatched bar). The set of bars labeled LHRH after SP shows the response to LHRH after an average of three (range, 2-4) previous SP applications with $400 \mu_{\mathrm{M}} \mathrm{GTP}(n=9$; solid bar $)$ or GDP $\beta S$ : GTP ( $n=4$ at $4: 1,1$ at 7.5:1, and 4 at $9: 1$; crosshatched bar). Values are mean \pm SD. $*$, significantly different from the first LHRH response by a paired $t$ test; $p<0.0005$.

desensitization of the LHRH receptors, matched experiments were run with GTP in the pipette (Fig. 1C). In this case, successive applications of LHRH resulted in reproducible decreases in $I_{\mathrm{M}}$.

The sensitivity of the agonist responses to block by GDP $\beta S$ varied from cell to cell, as illustrated in Figure 2. Both of these cells contained GDP $\beta$ : GTP $=4: 1$. In Figure $2 A$, the response to SP was decreased from an $86 \%$ inhibition of $I_{\mathrm{M}}$ at the first SP application to a $21 \%$ inhibition at the second SP application. LHRH then inhibited $I_{\mathrm{M}}$ by $85 \%$. In the cell in Figure $2 B, \mathrm{SP}$ inhibited $I_{\mathrm{M}}$ by $87 \%$ at the first application and by $43 \%$ at the third application. Muscarine then inhibited $I_{M}$ by $69 \%$. These plots also illustrate the agonist specificity of the effect of GDP $\beta S$ : the responses to SP were decreased, but the responses to LHRH and muscarine remained.

To quantify the degree of this selectivity of GDP $\beta$ S, we tested all of the permutations of the order of agonist application. First, consecutive applications of one agonist were made to observe a decrease in the response to that agonist in the presence of GDP $\beta$ S. Because of the variation in the effectiveness of GDP $\beta S$ from cell to cell, the number of applications of the first agonist was varied so that an effect of GDP $\beta$ S was observed. In most cells, three or four drug applications were required (see captions to Figs. 3-5). Next, a second agonist was applied. Control data

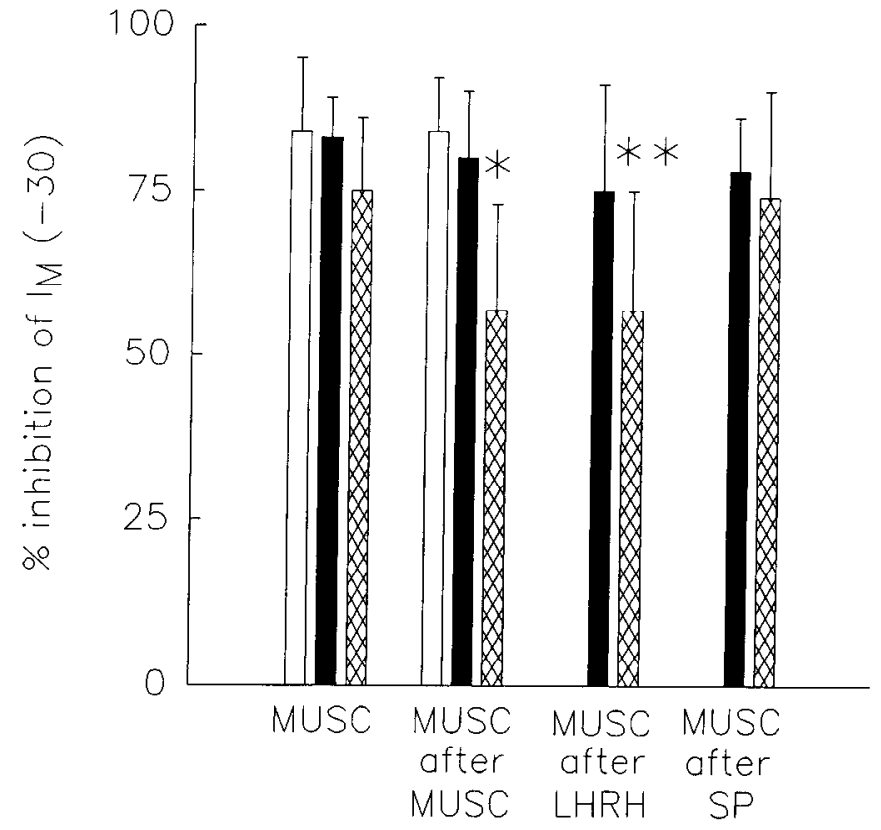

Figure 4. Inhibition of $I_{\mathrm{M}}$ by muscarine. The set of bars labeled MUSC shows the response to the first muscarine application with $40 \mu \mathrm{M}$ GTP ( $n=5$; open bar), $400 \mu \mathrm{M}$ GTP $(n=15$; solid bar $)$, or GDPBS:GTP $(n$ $=5$ at 7.5:1 and 10 at $9: 1 ;$ crosshatched bar). The set of bars labeled MUSC after MUSC shows the response to muscarine after an average of two (range, 1-3) previous muscarine applications with $40 \mu \mathrm{M}$ GTP ( $n=5$; open bar), $400 \mu \mathrm{M}$ GTP $(n=15$; solid bar), or GDP $\beta$ S:GTP $(n$ $=5$ at $7.5: 1$ and 10 at $9: 1$; crosshatched bar). The set of bars labeled MUSC after $L H R H$ shows the response to muscarine after an average of three (range, 2-4) previous LHRH applications with $400 \mu \mathrm{M}$ GTP $(n$ $=13$; solid bar) or GDP $\beta$ S:GTP $(n=1$ at $5.75: 1,6$ at $7.5: 1$, and 6 at $9: 1$; crosshatched bar). The set of bars labeled MUSC after SP shows the response to muscarine after an average of three (range, 2-4) previous SP applications with $400 \mu \mathrm{M}$ GTP ( $n=9$; solid bar) or GDP $\beta$ S:GTP ( $n$ $=4$ at $4: 1,1$ at $7.5: 1$, and 4 at $9: 1$; crosshatched bar). Values are mean \pm SD. $*$, significantly different from the first muscarine response by a paired $t$ test; $p<0.0001$. $^{* *}$, significantly different from the first muscarine response by a $t$ test for independent means; $p<0.02$.

were obtained by running matched cells with GTP $(400 \mu \mathrm{M}$, no GDP $\beta S$ ) in the pipette. In the matched cells, the agonists were applied at the same concentrations, in the same order and at the same intervals as in the cells with GDPBS. To be sure that the decrease in successive responses was due to the presence of GDP $\beta S$ and not to the decrease in GTP, additional controls were conducted with $40 \mu \mathrm{M}$ GTP in the pipette. These results are summarized in Figures 3-5.

Figure 3 shows the responses to LHRH under the various conditions. The presence of GDP $\beta$ S resulted in a significant decrease in successive responses to LHRH. This decrease was not noted with GTP ( 40 or $400 \mu \mathrm{M}$ ) in the pipette. Following previous applications of muscarine or SP, the responsiveness to LHRH was not significantly decreased.

The responses to muscarine revealed some overlap between the effects of GDP $\beta$ S on the LHRH and muscarine responses (Fig. 4). With GDP $\beta$ S in the pipette, the inhibition of $I_{M}$ by muscarine was decreased after previous applications of muscarine and after previous applications of LHRH, but not after previous applications of SP.

For SP, on average lower ratios of GDP $\beta$ S:GTP were used, yet the decrease in effectiveness of SP with successive applications was larger (Fig. 5). Part of this effect can be accounted for 
by desensitization. When GTP ( $400 \mu \mathrm{M})$ alone was in the cell, the responsiveness to SP was decreased with successive applications by a factor of 0.85 . With GDP $\beta S$ in the pipette, the last $\mathrm{SP}$ response was decreased by a factor of 0.55 compared to the first SP response. When an application of SP followed prior applications of LHRH or muscarine, the effectiveness of SP was not decreased.

\section{Discussion}

Numerous previous studies have found that GDP $\beta$ S inhibits receptor-mediated responses (e.g., see Trussell and Jackson, 1987; Breitwieser and Szabo, 1988; Pfaffinger, 1988; Brown et al., 1989; Shuba et al., 1990; Tokimasa and Akasu, 1990). Inhibition by GDP $\beta$ S has been taken as support that the process being studied involves $\mathrm{G}$-proteins.

In turkey erythrocytes, GDP $\beta$ S acted in a competitive manner versus GTP to inhibit adenylate cyclase stimulation (Eckstein et al., 1979). It was also found that GDP $\beta S$ was "tightly bound" in turkey erythrocytes. If we assume that the maximal concentrations of agonist used here activated more $G$-proteins than required to produce the maximal inhibition of $I_{M}$ and that GDP $\beta S$ remained bound following removal of agonist, our results can be explained in terms of G-protein interactions. Because there were more than enough G-proteins activated during the first agonist application to give a maximum response, the competition with GTP by GDP $\beta$ S did not decrease the observed inhibition of $I_{\mathrm{M}}$. Following washout of agonist, GDP $\beta S$ would remain bound to a proportion of G-proteins, and this GDP $\beta S$ bound population would not be available for participation in subsequent agonist responses. Consequently, responses to successive agonist applications would be smaller. It has been shown previously that successive responses to D-Ala ${ }^{6}-\mathrm{LHRH}$ and muscarine become smaller in the presence of GDP $\beta S$ (Lopez and Adams, 1989). A buildup of the effectiveness of GDP $\beta S$ with successive agonist applications to block cholinergic responses has also been shown in intestinal longitudinal muscle cells (Komori and Bolton, 1990).

If we accept the hypothesis that GDP $\beta S$ is acting on G-proteins, we conclude that each type of receptor seems to be associated with a separate population of $G$-proteins, with some overlap between the G-protein pools activated by LHRH and muscarine. When successive responses to LHRH were decreased by GDP $\beta S$, the responsivencss to muscarine was also decreased. However, when muscarine was applied first, a concomitant decrease in the LHRH response was not observed. If LHRH activates two populations of G-proteins, if one of these populations is also activated by muscarine, and if those activated by muscarine make up a minor proportion of the G-proteins activated by LHRH but a larger proportion of those activated by muscarine, such a result could be seen [see Kenakin and Morgan (1989) for a theoretical discussion of a single receptor coupled to two G-proteins]. The proportional decrease in responsiveness predicted for overlapping systems would depend on several factors: the number of receptors, G-proteins, and effector molecules affected by each agonist; the affinities of the various receptors for the different G-proteins, of the G-proteins for the effectors, and of GDP $\beta S$ for the G-proteins; and the stoichiometries of the numerous reactions. We observed a decrease in the LHRH response to 0.89 of control after previous muscarine applications.

It is not clear whether the distinction in the G-protein populations affected by the different agonists represents a diversity

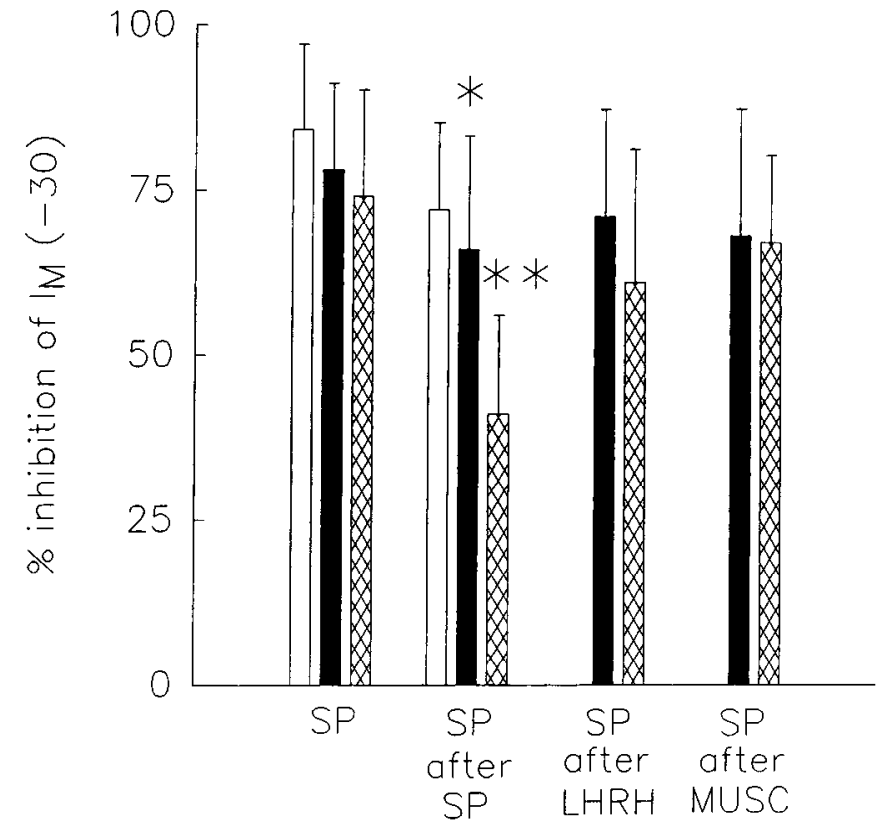

Figure 5. Inhibition of $I_{M}$ by SP. The set of bars labeled $S P$ shows the response to the first SP application with $40 \mu \mathrm{M}$ GTP ( $n=5$; open bar), $400 \mu \mathrm{M}$ GTP ( $n=12$; solid bar), or GDP $\beta$ S:GTP $(n=6$ at $4: 1,1$ at 7.5:1, and 5 at 9:1; crosshatched bar). The set of bars labeled SP after $S P$ shows the response to $S P$ after an average of three (range, 2-4) previous SP applications with $40 \mu \mathrm{M}$ GTP ( $n=5$; open bar), $400 \mu \mathrm{M}$ GTP ( $n=8$; solid bar), or GDP $\beta$ S:GTP $(n=6$ at $4: 1,1$ at $7.5: 1$, and 5 at $9: 1 ;$ crosshatched bar). The set of bars labeled $S P$ after $L H R H$ shows the response to SP after an average of three (range, 2-4) previous LHRH applications with $400 \mu \mathrm{M}$ GTP ( $n=9$; solid bar) or GDP $\beta$ S:GTP $(n=$ 1 at 5.75:1, 4 at 7.5:1, and 4 at $9: 1$; crosshatched bar). The set of bars labeled $S P$ after MUSC shows the response to muscarine after an average of four (range, 3-5) previous muscarine applications with $400 \mu \mathrm{M}$ GTP $(n=8$; solid bar $)$ or GDP $\beta$ S:GTP $(n=2$ at $7.5: 1$ and 6 at $9: 1$; crosshatched bar). Values are mean $\pm \mathrm{SD}$. ${ }^{*}$, significantly different from the first SP response by a paired $t$ test; $p<0.005$. ${ }^{* *}$, significantly different from the first $\mathrm{SP}$ response by a paired $t$ test; $p<0.0002$.

in molecular structure or a compartmentation of the G-proteins. However, if a physical compartmentation does exist, it must occur at the level of receptor $-\mathrm{G}$-protein coupling. With GTP and no GDP $\beta$ S in the recording electrode, each of these agonists is able to decrease $I_{M}$ by approximatcly $80 \%$ by decreasing the number of open M-channels by $80 \%$. This means that either the G-protein or some other diffusible messenger can reach $80 \%$ of the channels in the cell membrane; thus, the compartmentation would have to occur prior to this step.

Others have also suggested that different receptors may be coupled to different $\mathrm{G}$-proteins in bullfrog sympathetic neurons (Bley and Tsien, 1990). Muscarinic receptors affected M-current and leak current, but not Ca current, while LHRH, SP, and epinephrine affected all three types of channels. This suggested two possibilities: receptor-specific G-proteins that interact with different types of ion channels, or channel-specific G-proteins that are activated by different types of receptors. The present findings suggest that, for the M-current, receptor-specific G-proteins may be activated. Distinct $G$-protein populations have also been observed in biochemical studies on purified G-proteins and receptors. $\mathrm{G}_{i}$-subtypes differ in thcir ability to couple to $\mathrm{D}_{2}$ dopamine receptors and in the maximum rate of GTP hydrolysis that can be elicited by the $D_{2}$ receptor (Senogles et al., 1990). 
Alternatively, one could propose that GDP $\beta$ S was acting at the level of the receptor to exert agonist specific effects. With prolonged application of agonist, homologous desensitization does occur in these cells (Jan and Jan, 1982; Jones, 1985; Bosma and Hille, 1989). Our control experiments with GTP in the pipette showed that, for LHRH and muscarine, no desensitization was observed, and with SP, the degree of desensitization was small compared to the decreased responsiveness observed with GDP $\beta S$. The possibility exists that GDP $\beta$ S could act to enhance desensitization. Although we are aware of no evidence to support this suggestion, we cannot rule it out.

Another alternative could be that, upon receptor activation, GDP $\beta S$ binds to the receptor-coupled G-protein. Upon washout of agonist, however, the GDP $\beta$ S-bound G-protein does not uncouple from the receptor. Consequently, fewer receptors would be available for mediating successive responses to the agonist.

\section{References}

Bley DR, Tsien RW (1990) Inhibition of $\mathrm{Ca}^{2+}$ and $\mathrm{K}^{+}$channels in sympathetic neurons by neuropeptides and other ganglionic transmitters. Neuron 4:379-391.

Bosma MM, Hille B (1989) Protein kinase C is not necessary for peptide-induced suppression of $M$ current or for desensitization of the peptide receptors. Proc Natl Acad Sci USA 86:2943-2947.

Breitwieser GE, Szabo G (1988) Mechanism of muscarinic receptorinduced $\mathrm{K}^{+}$channel activation as revealed by hydrolysis-resistant GTP analogues. J Gen Physiol 91:469-493.

Brown DA (1988) $M$ currents. In: Ion channels (Narahashi T, ed) pp 55-94. New York: Plenum.

Brown DA (1990) G-proteins and potassium currents in neurons. Annu Rev Physiol 52:215-242.

Brown DA, Adams PR (1980) Muscarinic suppression of a novel voltage-sensitive $\mathrm{K}^{+}$-current in a vertebrate neurone. Nature 283:673676.

Brown DA, Marrion NV, Smart TG (1989) On the transduction mechanism for muscarine-induced inhibition of M-current in cultured rat sympathetic neurones. J Physiol (Lond) 413:469-488.

Eckstein F, Cassel D, Lefkovitz H, Lowe M, Selinger Z (1979) Gua- nosine 5'-O-(2-thiodiphosphate). An inhibitor of adenylate cyclase stimulation by guanine nucleotides and fluoride ions. J Biol Chem 254:9829-9834.

Fischmeister RF, Hartzell HC (1986) Mechanism of action of acetylcholine on calcium current in single cells from frog ventricle. J Physiol (Lond) 376:183-202.

Jan LY, Jan YN (1982) Peptidergic transmission in sympathetic ganglia of the frog. J Physiol (Lond) 327:219-246.

Jones SW (1985) Muscarinic and peptidergic excitation of bull-frog sympathetic neurones. J Physiol (Lond) 366:63-87.

Kenakin TP, Morgan PH (1989) Theoretical effects of single and multiple transducer receptor coupling proteins on estimates of the relative potency of agonists. Mol Pharmacol 35:214-222.

Komori S, Bolton TB (1990) Role of G-proteins in muscarinic receptor inward and outward currents in rabbit jejunal smooth muscle. J Physiol (Lond) 427:395-419.

Lopez HS, Adams PR (1989) A G protein mediates the inhibition of the voltage-dependent potassium $M$ current by muscarine, LHRH, substance $P$ and UTP in bullfrog sympathetic neurons. Eur J Neurosci $1: 529-542$

Pfaffinger P (1988) Muscarine and $t$-LHRH suppress M-current by activating an IAP-insensitive $G$ protein. J Neurosci 8:3343-3353.

Senogles SE, Spiegel AM, Padrell E, Iyengar R, Caron MG (1990) Specificity of receptor-G protein interactions: discrimination of $G$ subtypes by the $D_{2}$ dopamine receptor in a reconstituted system. $J$ Biol Chem 265:4507-4514.

Shuba YM, Hesslinger B, Trautwein W, McDonald TF, Pelzer D (1990) Whole-cell calcium current in guinea-pig ventricular myocytes dialysed with guanine nucleotides. J Physiol (Lond) 424:205-228.

Simmons MA, Becker JB, Mather RJ (1990) Desensitization of the inhibition of the M-current in sympathetic neurons: effects of ATP analogs, polyanions, and multiple agonist applications. Neuron 4: 557-562.

Tokimasa T, Akasu T (1990) ATP regulates muscarine-sensitive potassium current in dissociated bull-frog primary afferent neurones. J Physiol (Lond) 426:241-264.

Trussell LO, Jackson MB (1987) Dependence of an adenosine-activated potassium current on a GTP-binding protein in mammalian central neurons. J Neurosci 7:3306-3316.

Yellen $\mathrm{G}$ (1982) Single $\mathrm{Ca}^{2+}$-activated nonselective cation channels in neuroblastoma. Nature 296:357-359. 